\title{
Adoption of $B t$ Cotton Growers for Control of Pink Bollworm
}

\author{
A. M. Todkar*, S. R. Jakkawad and S. B. Khodake \\ Department of Extension Education, College of Agriculture, Parbhani (M.S.) India \\ *Corresponding author
}

\section{A B S T R A C T}

K e y w o r d s
Bt cotton, Pink
bollworm,
Adoption,
Pheromone trap,
Trap crop etc
Article Info
Accepted:
$\begin{aligned} & \text { 18 November } 2020 \\ & \text { Available Online: } \\ & 10 \text { December } 2020\end{aligned}$

\section{Keywords}

Bt cotton, Pink Pheromone trap,

\section{Article Info}

Accepted: Available Online:
The present study on adoption of $B t$ cotton growers for control of pink bollworm was conducted in Parbhani district of Marathwada region in Maharashtra State. The data were collected through personal interview with the help of interview schedule by contacting 120 respondents. The data was processed by making primary and secondary tables. The information of qualitative nature was converted into quantitative from form and computation of score was done for each of the independent and dependent variables. The study showed that majority $(66.66 \%)$ of the farmers had medium level adoption while other 8.33 per cent of farmers belongs to high adoption level category; whereas, only 25.00 per cent of farmer belongs to low adoption level category of about control of pink bollworm in cotton crop. Variable like education, area under $B t$ cotton, innovativeness and source of irrigation observed to be had positive and significant relationship with the adoption of respondents for control of pink bollworm. While social participation, source of information, extension contact, economic motivation, risk orientation found positive and highly significant with adoption of respondents for control pink bollworm. Where, variable like age, land holding and annual income cotton found non-significant relationship with adoption of respondents. And variable like farming experience is negatively significant with adoption of cotton growers for control of pink bollworm

\section{Introduction}

Cotton (Gossypium Spp.) 'king of fiber' which closely linked to the human civilization and economically important germ comprising about 40 species of which four are commercially cultivated for cotton lint and seed. Cotton fiber was discovered more than 4000 years ago in Coastal Peru and MohenjoDaro in the Indus valley. Cotton is the second most important field crop in Indian for the production of table oil; 13.7 per cent of the 7.88 million tons of table oil produced in
India is obtained from Cotton seed. Cottonseed has also become the main ingredient $(33.00 \%)$ in processed animal fodder, with soya, rapeseed and groundnuts lagging far behind. The "pressed cake" that remains after the oil extracted sometimes processed in animal feed. $B t$ proteins can be found in the seed and the pressed cake of $B t$ cotton, but not in the oil. The Cry toxins are specifically toxic to specific classes of insects. For example the Cry 1Ac is toxic to three species of cotton bollworms, but is less toxic to the tobacco caterpillar, Spodoptera litura 
and is non-toxic to other classes of insects which are sap-sucking pests such as mealy bugs, jassids, aphids, whiteflies etc. Control of pink bollworms involves all available techniques for managing pest populations with the aim of reducing pesticide use while maintaining profitability, yield and fiber quality. Crop, insect pests, diseases, natural enemies, cropping practices and patterns and prevalent weather are essentially to be considered simultaneously to improve decision making for profitable and sustainable control.

\section{Results and Discussion}

The study was conducted in randomly selected Parbhani district of Marathwada region.
In Parbhani district there are 9 talukas. out of these three talukas Parbhani, Purna and Pathri was selected randomly as area and infestation of pink bollworm was more in these region. The names of villages which come under the selected talukas were collected from the secondary source. To obtain the desired no of respondent of villages this comes under Parbhani district. Ten $B t$ cotton growers were selected randomly from each village to comprise the sample of 120 respondents for study. Respondents were selected according to the considerable area under $B t$ cotton growers. The study sample consists of having 120 respondents from three talukas. The Data were analyzed by using mean, S.D., and coefficient of correlation methods were used for data analysis (Fig. 1).

Table.1 Distribution of respondents Adoption for control of pink bollworm

\begin{tabular}{|c|c|c|c|}
\hline Sr. No. & Category & Frequency & Per cent \\
\hline 1. & Low (Up to 7) & 30 & 25.00 \\
\hline 2. & Medium (7 to 10) & 80 & 66.66 \\
\hline 3. & High (Above 10) & 10 & 8.33 \\
\hline & Total & $\mathbf{1 2 0}$ & $\mathbf{1 0 0 . 0 0}$ \\
\hline
\end{tabular}

Fig.1 Distribution of respondents according to their adoption for control of pink bollworm

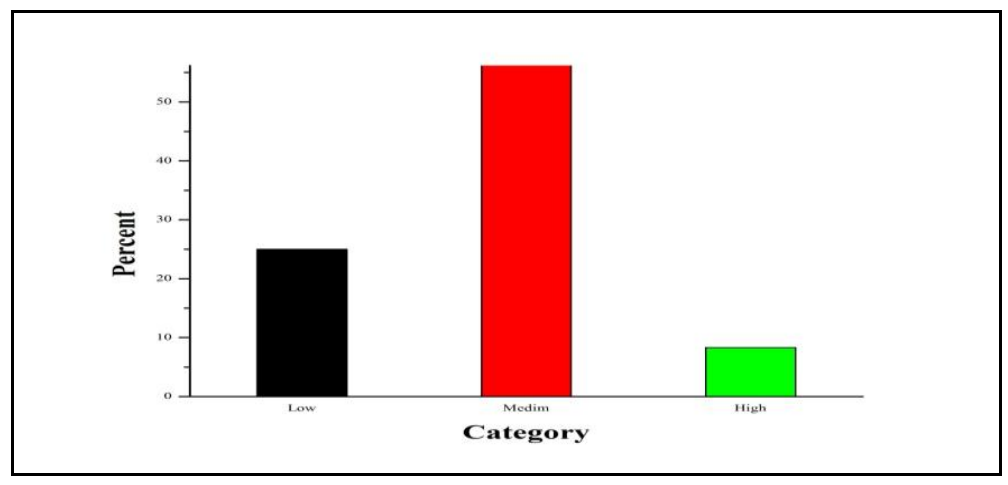

\section{Observation and analysis}

The findings of the study as well as discussion have been showed under the following tables:
From the data reported in above Table 1 that majority $(66.66 \%)$ of the farmers had medium level adoption for control of pink bollworm while other 8.33 per cent of farmers belongs to high adoption level category for control of 
pink bollworm; whereas, only 25.00 per cent of farmer belongs to low adoption level category of about control of pink bollworm in cotton crop.

In conclusion the study observed that the majority 66.66 per cent of the respondent had medium level adoption while other 8.33 per cent of respondent Adoption for control of pink bollworm belongs to high adoption level category; whereas, only 25.00 per cent of respondents belongs to low adoption level category of about control of pink bollworm in cotton crop.

\section{References}

Padwal D., Jahanar, M.H., Bose, D.K. and Srivastava J.P. (2018). A study on knowledge of $B t$ cotton cultivation practices in Rangareddy district of Telangana. Journal of Pharmacognosy and Phytochemistry, 7(3): 2204-2205.

Verma, Kumar, S. Rai, D.P. and Verma, L.R.(2015). Knowledge and adoption of recommended chilli production technology by the farmers of Raipur district. Agric. Update, 10(2): 120-125.

Pavan Kumar, P. and Dhorey, R.K. (2017). Extent of Adoption of Farmers about Bt Cotton Practices in Warangal District of Telangana State, India. Int. J. Curr. Microbiol. App. Sci. 6(11): 824829.

Maraddi, G. N., Metti, S. K. and Tulsiram, J. (2014). Extent of adoption of improved technologies by groundnut farmers and constraints analysis in Raichur district of Karnataka. Karnataka J. Agric. Sci., 27 (2): 177-180.

\section{How to cite this article:}

Todkar, A. M., S. R. Jakkawad and Khodake, S. B. 2020. Adoption of Bt Cotton Growers for Control of Pink Bollworm. Int.J.Curr.Microbiol.App.Sci. 9(12): 2731-2733. doi: https://doi.org/10.20546/ijcmas.2020.912.325 